\title{
Penerapan Model Pembelajaran Berbasis Masalah untuk Meningkatkan Hasil Belajar IPA Siswa Kelas V SD Negeri 028 Rimbo Panjang Kecamatan Tambang
}

\author{
Damsir Ali*, Muhamad Syarifudin*, Nurhasanah Bakhtiar*** \\ *** Pendidikan Guru Madrasah Ibtidaiyah, Universitas Islam Negeri Sultan Syarif Kasim Riau
}

\section{INFO ARTIKEL \\ Riwayat Artikel: \\ Diterima: 20-12-2019 \\ Disetujui: $18-04-2020$}

Kata kunci:
Hasil Belajar IPA
Pembelajaran Berbasis Masalah,
Hasil Belajar,
Metode Peer Teaching

\section{Alamat Korespondensi:}

Damsir Ali

Program Studi Megister Pendidikan Guru Madrasah Ibtidaiyah

Universitas Islam Negeri Sultan Syarif Kasim Riau, Pekanbaru

E-mail:damsirali92@gmail.com

\section{ABSTRAK}

Abstract: The problem in this study is the low science learning outcomes of fifth grade students of SD Negeri 028 Rimbo Panjang, this can be seen from the average daily scores of students which are 59.19 , while the KKM set is 65 . The method of this study is classroom action research aimed at to improve student science learning outcomes. Data were collected through learning outcomes tests and observation sheets which were then analyzed using quantitative descriptive. After conducting research and data analysis found an increase in student learning outcomes from the initial average value of 59.19 to 77.81 . Teacher activity increased from $70 \%$ to $95 \%$. Student activity also increased from $65 \%$ to $90 \%$. Based on the results of this study it can be concluded that the application of the Problem Based Learning (PBM) model can improve the science learning outcomes of fifth grade students of SD Negeri 028 Rimbo Panjang, Tambang District.

\begin{abstract}
Abstrak: Permasalahan dalam penelitian ini adalah rendahnya hasil belajar IPA siswa kelas V SD Negeri 028 Rimbo Panjang, hal ini dilihat dari nilai rata-rata ulangan harian siswa yaitu 59,19, sedangkan KKM yang ditetapkan adalah 65 . Metode penelitian ini adalah penelitian tindakan kelas (PTK) yang bertujuan untuk meningkatkan hasil belajar IPA siswa. Data dikumpulkan melalui tes hasil belajar dan lembar observasi yang kemudian dianalisis secara deskriptif kuantitatif. Setelah dilakukan penelitian dan analisis data ditemukan peningkatan hasil belajar siswa yaitu dari nilai rata-rata awal 59,19 menjadi 77,81. Aktifitas guru meningkat dari 70\% menjadi 95\%. Aktifitas siswa juga mengalami peningkatan dari $65 \%$ menjadi $90 \%$. Berdasarkan hasil penelitian ini dapat disimpulkan bahwa penerapan model Pembelajaran Berbasis Masalah (PBM) dapat meningkatkan hasil belajar IPA siswa kelas V SD Negeri 028 Rimbo Panjang Kecamatan Tambang.
\end{abstract}

\section{LATAR BELAKANG}

Ilmu Pengetahuan Alam merupakan salah satu mata pelajaran yang dipelajari oleh siswa di Sekolah Dasar. IPA adalah ilmu tentang alam yang membimbing siswa kepada proses berpikir, mengamati, meneliti, dan memahami tentang seluk beluk alam dan antariksa serta mempelajari makhluk hidup. Dalam pembelajaran IPA hendaknya membantu siswa untuk mencari tahu tentang alam sekitar secara sistematis untuk menguasai pengetahuan, fakta-fakta, konsep-konsep, prinsipprinsip, proses penemuan, dan memiliki sikap ilmiah. Tujuan yang hendak dicapai oleh pembelajaran IPA adalah meletakkan dasar kecerdasan, pengetahuan, kepribadian, akhlak mulia, serta keterampilan untuk hidup mandiri dan mengikuti pendidikan lebih lanjut. Tujuan tersebut menghendaki bahwa suatu pembelajaran pada dasarnya tidak hanya mempelajari tentang konsep, teori dan fakta tapi juga aplikasi dalam kehidupan sehari-hari (Benyamin Salu dan Tadius, 2019). Oleh sebab itu, materi 
pembelajaran tidak hanya tersusun atas hal-hal sederhana yang bersifat hapalan dan pemahaman saja, tetapi juga tersusun atas materi yang komplek yang memerlukan analisis, aplikasi dan sintesis.

Kenyataannya di sekolah dasar selama ini kita seringkali mendengar berbagai keluhan yang dialami siswa tentang beratnya mereka mengikuti beban pelajaran di sekolah. Mereka dituntut untuk lebih banyak mempelajari konsep-konsep dan prinsip-prinsi IPA secara keseluruhan. Cara pembelajaran ini menyebabkan siswa pada umumnya hanya mengenal banyak peristilahan dalam IPA secara hapalan tanpa makna. Selain itu, karena banyaknya konsep-konsep dan prinsip-prinsip IPA yang dipelajari menyebabkan kejenuhan pada siswa dalam belajar. Dengan demikian, belajar IPA hanya diartikan sebagai pengenalan konsep-konsep, prinsip-prinsip dan peristilahan. Pada hakikatnya IPA dalam kehidupan sehari-hari diperlukan untuk memenuhi kehidupan manusia melalui pemecahan masalah-masalah yang dapat di identifikasikan. Mulyasa (2017) menyatakan bahwa mata pelajarn IPA di SD/MI perlu diberikan dengan tujuan agar peserta didik memiliki kemampuan dalam mengembangkan rasa ingin tahu, pengatahuan dan pemahaman konsep-konsep IPA serta keterampilan proses, untuk memecahkan masalah dan membuat keputusan dalam menyelidiki alam sekitar yang bermanfaat dan dapat diterapkan dalam kehidupan sehari-hari.

Berdasarkan Observasi dan wawancara dengan Guru kelas V SD Negeri 028 Rimbo Panjang Kecamatan Tambang pada maka diperoleh data. Jumlah siswa 31 orang. Kriteria Ketuntasan Minimal (KKM) yang di tetapkan 65. Jumlah siswa yang mencapai KKM 13 orang (41,93\%), sedangkan jumlah siswa yang belum mencapai KKM 18 orang (58,07\%). Dengan nilai rata-rata kelas 59,19. Rendahnya hasil belajar IPA siswa kelas V SD Negeri 028 Rimbo Panjang Kecamatan Tambang ini disebabkan oleh gurunya yang belum menerapkan model pembelajaran yang sesuai dengan karakteristik dan ciri IPA sehingga berdampak pada kegiatan siswa dalam pembelajaran. Hal ini dapat dilihat dari gejala-gejala diantaranya siswa kurang aktif dan merasa tidak tertarik dalam belajar karena pembelajaran hanya berpusat kepada guru sehingga siswa merasa jenuh dalam proses belajaran mengajar karena guru hanya menekankan pada banyaknya konsep-konsep dan prinsip-prinsip yang dipelajari dalam IPA. sehingga siswa hanya mengenal banyaknya peristilahan dalam pembelajaran IPA tanpa makna.

Dengan adanya permasalahan tersebut, penulis ingin melaksanakan perbaikan terhadap proses belajar siswa dengan memilih dan menggunakan model pembelajaran yang paling efektif untuk mencapai tujuan dari pembelajaran tersebut. Salah satunya dengan cara memilih model pembelajaran yang tepat yaitu model pembelajaran berbasis masalah yang merupakan model pembelajaran yang didasarkan pada banyaknya permasalahan yang membutuhkan penyelidikan autentik, yakni penyelidikan yang membutuhkan penyelesaian nyata dari permasalahan nyata. Agar proses pembelajaran menjadi menyenangkan dan siswa dapat mengerjakan tugas sesuai cara penyelesaian soal pemecahan masalah, sehingga hasil belajar IPA siswa dapat meningkat. Model Problem Based Learning merupakan model pembelajaran yang melibatkan siswa dengan masalah nyata yang sesuai minat dan perhatiannya, sehingga motivasi dan rasa ingin tahu menjadi meningkat (Ratna Dewi AR, Musa Thahir, 2018). Model pembelajaran berbasis masalah ialah suatu model pembelajaran yang menuntut peserta didik mandiri dan mampu mencari serta memecahkan masalah yang ada. Barrow mendefinisikan pembelajaran berbasis masalah sebagai "Pembelajaran yang diperoleh melalui proses menuju pemahaman akan resolusi suatu masalah. Masalah tersebut dipertemukan pertamatama dalam proses pembelajaran". Peserta dituntut untuk mampu memecahkan masalah dari masalah yang ada, sehingga peserta didik lebih mandiri dan mampu mengembangkan kemampuan berpikirnya (Huda, 2013). Dengan demikian, siswa diharapkan dapat mengembangkan cara berfikir dan keterampilan yang lebih tinggi.

Peran guru dalam pembelajaran berbasis masalah di dalam kelas, yaitu mengajukan masalah atau mengorientasikan peserta didik kepada masalah kehidupan nyata sehari-hari, memfasilitasi atau membimbing penyelidikan misalnya pengamatan atau melakukan percobaan serta mendukung belajar siswa. Pembelajaran berdasarkan masalah tidak dirancang untuk membantu guru memberikan informasi yang sebanyakbanyaknya kepada peserta didik, akan tetapi pembelajaran berbasis masalah dikembangkan untuk membantu peserta didik mengembangkan kemampuan berpikir, pemecahan 
masalah dan keterampilan intelektual, belajar berbagai peran orang dewasa melalui pelibatan mereka dalam pengalaman nyata dan menjadi pembelajaran yang mandiri. Peran guru sebagai fasilitator untuk mengarahkan siswa tentang "konsep apa yang diperlukan untuk memecahkan masalah", "apa yang harus dilakukan" atau "bagaimana melakukannya" dan seterusnya. Dari paparan tersebut dapat diketahui bahwa penerapan pembelajaran berbasis masalah dapat mendorong peserta didik mempunyai inisiatif untuk belajar secara mandiri. Pengalaman ini sangat diperlukan dalam kehidupan sehari-hari dimana berkembangnya pola pikir dan pola kerja seseorang bergantung pada bagaimana dia membelajarkan dirinya. Model ini dipilih karena ciri utama pembelajaran IPA adalah dimulai dengan pertanyaan atau masalah yang dilanjutkan dengan arahan guru pada siswa untuk menggali informasi, mengkonfirmasi dengan pengetahuan yang sudah dimiliki dan mengarahkan pada tujuan apa yang belum dan harus diketahui.

\section{METODE}

Penelitian ini dilakukan pada kelas V SD Negeri 028 Rimbo Panjang Kecamatan Tambang Kabupaten Kampar. Bentuk penelitian ini adalah penelitian tindakan kelas (PTK) kolaboratif. Pelaksanaan tindakan dilakukan oleh peneliti sendiri, sedangkan guru sebagai pengamat selama proses pembelajaran. Penelitian ini terdiri dari tiga siklus yaitu siklus pertama, siklus kedua, dan siklus ketiga. Siklus penelitian tindakan kelas yang akan dilakukan terdiri atas beberapa tahap. Kegiatan-kegiatan yang akan dilaksanakan pada tiap tahapan dalam penelitian ini adalah sebagai berikut (1) perencanaan tindakan: tahap perencanaan merupakan awal yang harus dilaksanakan sebelum melakukan suatu tindakan sehingga kegiatan yang akan dilakukan lebih terarah. Pada tahap perencanaan ini dilakukan tindakan menyusun silabus, rencana pelaksanaan pembelajaran, lembar kerja siswa, dan lembar pengamatan (observasi) sebagai perangkat pembelajaran yang akan dilaksanakan dengan berpandu pada model pembelajaran berbasis masalah. (2) pelaksanaan tindakan: pelaksanaan tindakan merupakan penerapan dari perencanaan yang telah dibuat. (3) pengamatan: pengamatan tentang apa yang terjadi dalam tindakan, mengamati kegiatan siswa selama proses pembelajaran yang dilakukan oleh observer. (4) refleksi: mengkaji, melihat dan mempertimbangkan atas hasil atau dampak dari siklus I diperbaiki pada tindakan siklus II, melihat hasil atau dampak pada siklus II diperbaiki pada siklus III karena dalam penelitian ini terjadi tiga siklus sehingga setiap kegiatannya harus selalu memperhatikan ketelitian. Data yang digunakan dalam penelitian ini adalah data tentang aktivitas siswa dan guru selama proses pembelajaran berlangsung dan data hasil belajar IPA siswa.

Untuk mengetahui peningkatan hasil belajar siswa setelah menerapkan model pembelajaran berbasis masalah, penulis menggunakan analisis deskriptif.

Aktivitas Guru dan Siswa

Data tentang aktivitas guru dan siswa dalam proses pembelajaran dihitung dengan menentukan persentase rata-rata yang diperoleh dengan rumus :

Keterangan :

$$
N R=\frac{J S}{S M} \times 100 \%
$$

$\mathrm{NR}=$ Persentase nilai rata-rata aktivitas (guru/siswa)

JS = Jumlah skor aktivitas yang di lakukan

$\mathrm{SM}=$ Skor maksimal yang didapat dari aktivitas (guru/siswa)

Ketuntasan Individu

Ketuntasan belajar siswa secara individu dapat dinyatakan apabila hasil belajar siswa (individu) lebih besar atau sama dengan KKM yang telah ditetapkan, yaitu 65, maka siswa tersebut dikatakan tuntas, sedangkan jika hasil belajar siswa secara individu lebih kecil dari KKM yang telah ditetapkan, maka siswa tersebut dikatakan tidak tuntas. Ketuntasan Klasikal

Ketuntasan klasikal

Ketuntasan klasikal tuntas jika sekurang-kurangnya 70\% dari keseluruhan siswa yang ada di kelas tersebut memperoleh nilai $\geq 65$. Ketuntasan secara klasikal dihitung dengan rumus: 
4 Instructional Development Journal (IDJ), Vol. 3, No. 1, April 2020, Hal. 1-7

Keterangan :

$$
\mathrm{PK}=\frac{S T}{N} \times 100 \%
$$

PK = Persentase Ketuntasan

$S T \quad=$ Jumlah Siswa yang Tuntas

$N \quad=$ Jumlah Siswa Keseluruhan

Hasil Belajar

Untuk menentukan hasil belajar siswa digunakan rumus sebagai berikut:

$$
\mathrm{S}=\frac{\mathrm{R}}{\mathrm{N}} \mathrm{X} 100, \quad \text { (Ngalim Purwanto, 2014) }
$$

Keterangan :

$\mathrm{S} \quad=$ Nilai yang diharapkan

$\mathrm{R}=$ Jumlah skor dari item atau soal yang dijawab benar

$\mathrm{N} \quad=$ Skor maksimum dari tes tersebut

Peningkatan Hasil Belajar

Peningkatan hasil belajar yang telah didapatkan, dianalisis dengan menggunakan rumus persentase sebagai berikut :

Keterangan :

$$
P=\frac{\text { Poserate }- \text { Baserate }}{\text { Baserate }} \times 100 \%, \quad \text { ( Zainal Aqib dkk, 2015) }
$$

P

Poserate $\quad=$ Nilai rata - rata sesudah tindakan

Baserate $\quad=$ Nilai rata - rata sebelum tindakan

Tabel 1 Kategori Aktivitas Guru dan Siswa

\begin{tabular}{cc}
\hline Persentase Interval & Kategori \\
\hline $81-100$ & Sangat Baik \\
$61-80$ & Baik \\
$51-60$ & Cukup \\
\hline Kurang dari 50 & Kurang \\
\hline
\end{tabular}

\section{HASIL DAN PEMBAHASAN}

Penelitian ini terdiri dari 3 siklus dengan sembilan kali pertemuan dan dua jam pelajaran tiap kali pertemuan. Dimana sembilan kali pertemuan tersebut terdiri dari enam kali pelaksanaan pembelajaran dan tiga kali ulangan siklus (siklus I, II, III). Proses pembelajaran dilaksanakan menggunakan model pembelajaran berbasis masalah, pada setiap pertemuan observer (wali kelas) mengamati aktivitas guru dan siswa dengan menggunakan lembar pengamatan.

Adanya peningkatan aktivitas guru dan siswa dari siklus I ke siklus II, dan siklus III. Untuk aktivitas guru, pada siklus I pertemuan pertama sebesar $70 \%$, pada pertemuan kedua meningkat menjadi $75 \%$, meningkat lagi pada siklus II pertemuan pertama yaitu $85 \%$ dan pertemuan kedua mengalami meningkatan menjadi $90 \%$ dan kembali mengalami peningkatan pada siklus III pertemuan pertama menjadi $95 \%$ dan pada pertemuan akhir mendapat skor yang sama yaitu $95 \%$. Untuk aktivitas siswa, pada siklus I pertemuan pertama $65 \%$, pada pertemuan kedua mengalami peningkatan menjadi $70 \%$. Siklus II pertemuan pertama meningkat menjadi $75 \%$, dan pada pertemuan kedua mendapatkan persentase yang sama yaitu $85 \%$. Pada siklus III persentase aktivitas siswa yaitu $85 \%$, dan mengalami peningkatan pada pertemuan terakhir mencapai $90 \%$.

Perbandingan ketuntasan individu dan klasikal skor dasar, siklus I, siklus II dan siklus III dengan menerapkan model pembelajaran berbasis masalah (PBM) pada siswa kelas V SD Negeri 028 Rimbo Panjang Kecamatan Tambang dapat dilihat pada tabel berikut : 
Damsir Ali, dkk, Penerapan Model Pembelajaran ....5

Tabel 2. Ketuntasan Individu dan Klasikal

\begin{tabular}{lccccc}
\hline \multirow{2}{*}{ Pertemuan } & \multicolumn{2}{c}{ Ketuntasan Individu } & Ketuntasan & Persentase & \multirow{2}{*}{ Kategori } \\
\cline { 2 - 3 } & Siswa Tuntas & Siswa Tidak Tuntas & Klasikal & Kelulusan & TT \\
\hline Skor Dasar & 31 & 13 & 18 & $41,93 \%$ & TT \\
Siklus I & 31 & 19 & 12 & $61,29 \%$ & T \\
Siklus II & 31 & 25 & 6 & $80,64 \%$ & T \\
Siklus III & 31 & 29 & 2 & $93,54 \%$ & \\
\hline
\end{tabular}

Dari tabel 2 terlihat jumlah siswa yang tuntas secara individu dan persentase ketuntasan secara klasikal meningkat dari skor dasar, ulangan siklus I ulangan siklus II, dan ulangan siklus III. Hasil belajar IPA siswa dengan Penerapan Model Pembelajaran Berbasis Masalah

Tabel 3. Hasil belajar siswa pada UH 1, UH 2 dan UH 3

\begin{tabular}{cccc}
\hline No & Aspek & Jumlah & Rata-rata \\
\hline 1 & Skor Dasar & 1835 & 59,19 \\
2 & UH 1 & 2036 & 65,67 \\
3 & UH 2 & 2260 & 72,91 \\
4 & UH 3 & 2412 & 77,81 \\
\hline
\end{tabular}

Dari tabel 3 di atas terdapat empat aspek dalam hasil belajar siswa. Skor dasar, seluruh nilai 31 orang siswa pada semester ganjil maka jumlah nilai IPA siswa kelas V SD Negeri 028 Rimbo Panjang Kecamatan Tambang adalah 1835 dengan rata-rata kelas 59,19. Setelah mendapatkan nilai yang cukup rendah pada semester ganjil, maka dilakukan tindakan penerapan model pembelajaran berbasis masalah (PBM) pada kelas tersebut, pada siklus I terjadi peningkatan pada hasil belajar siswa dilihat dari hasil Ulangan Harian I, dengan jumlah nilai 2036 dan rata-rata 65,67. Ulangan Harian II , terjadi peningkatan nilai siswa pada siklus II ini dapat dilihat dari hasil Ulangan Harian II jumlah nilai siswa secara keseluruhan yaitu 2260 dengan rata-rata kelas 72,91. Sedangkan pada Ulangan Harian siklus III, terjadi peningkatan lagi yaitu jumlah nilai pada siklus III ini yaitu 2412 dengan rata-rata kelas 77,81.

Berdasarkan pengolahan data hasil belajar siswa yang telah dilakukan, diperoleh fakta bahwa sebelum adanya tindakan dan sesudah adanya tindakan ada perubahan rata-rata hasil belajar siswa yang diperoleh dari hasil ulangan harian terlihat bahwa hasil belajar siswa mengalami peningkatan. Hal tersebut dapat terlihat dari skor dasar yang hanya 59,19 dan setelah dilakukannya tindakan dengan menerapkan model pembelajaran berbasis masalah, hasil belajar siswa mengalami peningkatan rata-rata hasil ulangan siklus I yaitu 65,67 dengan kategori cukup, meningkat pada rata-rata hasil ulangan siklus II menjadi 72,91 dengan kategori baik, kemudian meningkat lagi pada rata-rata hasil ulangan siklus III menjadi 77,81 dengan kategori baik.

Dari data tersebut terlihat bahwa hasil belajar siswa sebelum dan sesudah dilakukan tindakan mengalami peningkatan. Peningkatan ini terjadi disebabkan karena adanya refleksi yang dilakukan setiap akhir siklus dan siswa sudah terbiasa dengan model pembelajaran berbasis masalah. Selain itu, peningkatan hasil belajar dapat tercapai dengan baik karena guru menguasai pembelajaran berbasis masalah. Hasil penelitian ini diperkuat oleh hasil penelitian yang dilakukan oleh Nina Nurliani, Herman Subarjah, Atep Sujana (2016) bahwa pembelajaran IPA dengan menggunakan model pembelajaran berbasis masalah dan pembelajaran konvensional dapat meningkatkan hasil belajar IPA peserta didik pada materi peristiwa alam. Pembelajaran dengan model pembelajaran berbasis masalah lebih baik dibandingkan model pembelajaran konvensional. Hasil penelitian lain juga menunjukkan bahwa terdapat perbedaan hasil belajar IPA antara kelompok siswa yang dibelajarkan dengan model pembelajaran berbasis masalah dengan kelompok siswa yang dibelajarkan dengan model pembelajaran konvensional (I Wayan Wijaya, I Wayan Lasmawan, I Wayan Suastra, 2015). Berdasarkan hasil penelitian tersebut dapat disimpulkan bahwa Pembelajaran Berbasis Masalah dapat meningkatkan hasil belajar dan aktifitas siswa dalam pembelajaran. Dalam proses pembelajaran, kebermaknaan tidak hanya terletak pada model pembelajaran yang digunakan, tetapi juga diartikan sebagai kesesuaian antara 
perencanaan, pelaksanaan, dan evaluasi belajar. Seperti diungkapkan dalam hubungannya dengan proses belajar mengajar bahwa tujuan pembelajaran, proses belajar mengajar dan prosedur evaluasi saling berkaitan dan tidak bisa dipisahkan.

Kualitas pengajaran guru menjadi penentu hasil belajar siswa, ini sesuai dengan pendapat Nana Sudjana (2017) mengatakan bahwa faktor dominan yang mempengaruhi hasil belajar ialah kualitas pengajaran. Artinya apabila seorang guru dapat menguasai materi pelajaran dan pengajaran maka akan berpengaruh terhadap hasil belajar siswa, sehingga hasil belajar siswa dapat meningkat. Seiiring dengan perkembangan zaman saat ini, kemampuan berpikir kritis menjadi kemampuan yang sangat diperlukan agar siswa sanggup menghadapi perubahan keadaan atau tantangan-tantangan di dalam kehidupan yang selalu berkembang. Maka model pembelajaran berbasis masalah adalah model pembelajaran yang paling tepat karena pembelajaran berbasis masalah merupakan model pembelajaran yang efektif untuk pengejaran proses berpikir tingkat tinggi. Pembelajaran ini membantu siswa untuk memproses informasi yang sudah jadi dalam benaknya dan menyusun pengetahuan mereka sendiri tentang dunia sosial dan sekitarnya. Pembelajaran berbasis masalah dikembangkan berdasarkan teori psikologi kognitif yang menyatakan bahwa belajar adalah suatu proses dimana pembelajaran secara aktif mengkontruksi pengethuannya melalui interaksi dengan lingkungan belajar yang dirancang oleh fasilitator pembelajaran. teori yang dikembangkan mengandung dua prinsip penting, yaitu belajar adalah proses konstruksi bukan proses menerima (receptive process) dan belajar dipengaruhi oleh interaksi sosial dan sifat kontekstual dari pelajaran (Damanhuri Daud dan Mahmud Alpusari,2011).

Pada pembelajaran berbasis masalah siswa diberikan masalah yang berdasarkan pengalaman mereka dalam kehidupan sehari-hari atau yang pernah mereka jumpai. Dengan masalah ini membuat siswa termotivasi dan terlibat aktif untuk menyelesaikan masalah yang diberikan dan mencapai tujuan pembelajaran yang diharapkan. Hal ini ditunjukkan dengan jumlah siswa yang mencapai KKM setelah dilakukan tindakan dibandingkan sebelum dilaksanakan tindakan semakin meningkat.

\section{SIMPULAN DAN SARAN Simpulan}

Berdasarkan hasil penelitian dan pembahasan, dapat disimpulkan bahwa penerapan model pembelajaran berbasis masalah dapat meningkatkan hasil belajar IPA siswa kelas V SD Negeri 028 Rimbo Panjang Kecamatan Tambang. Peningkatan yang terjadi dapat dilihat dari hal-hal berikut: 1) Pada penerapan model pembelajaran berbasis masalah untuk persentase aktivitas guru pada siklus I pertemuan pertama sebesar 70\%, pada pertemuan kedua meningkat menjadi 75\%, meningkat lagi pada siklus II pertemuan pertama yaitu $85 \%$ dan pertemuan kedua mengalami peningkatan menjadi $90 \%$ dan kembali mengalami peningkatan pada siklus III pertemuan pertama menjadi $95 \%$ dan pada pertemuan akhir mendapat persen yang sama yaitu 95\%; 2) Persentase aktivitas siswa pada siklus I pertemuan pertama $65 \%$, pada pertemuan kedua mengalami peningkatan menjadi $70 \%$. Siklus II pertemuan pertama meningkat menjadi $75 \%$, dan pada pertemuan kedua mendapatkan persentase yang sama yaitu $85 \%$. Pada siklus III persentase aktivitas siswa yaitu $85 \%$, dan mengalami peningkatan pada pertemuan terakhir mencapai 90\%; dan 3) Rata-rata hasil belajar siswa pada skor dasar adalah 59,19. Meningkat menjadi 65,67 pada UH siklus I dengan persentase peningkatan $10,94 \%$. Pada UH siklus II nilai rata-rata meningkat menjadi 72,91 dengan persentase peningkatan 10,90\%. Pada UH siklus III meningkat lagi dengan rata-rata 77,81 dengan persentase peningkatan 6,82\%. Ketuntasan secara klasikal mengalami peningkatan dari data awal 41,39\% naik 19,36\% ke siklus I menjadi 61,29\% tetapi belum dikatakan tuntas secara klasikal. Pada siklus II kembali naik 19,35\% menjadi 80,64\% dengan kategori tuntas, kemudian pada siklus III kembali mendapatkan kenaikan 12,90\% menjadi 93,54\%. Dengan penerapan model pembelajaran berbasis masalah dapat meningkatkan hasil belajar IPA siswa kelas V SD Negeri 028 Rimbo Panjang Kecamatan Tambang. 


\section{Saran}

Dari penelitian ini, penulis memberikan saran untuk pendidik apabila melakukan pembelajaran hendaklah menggunakan pendekatan pembelajaran yang sesuai dan menarik bagi siswa sehingga membantu meningkatkan motivasi, kreativitas, dan hasil belajar siswa salah satunya adalah dengan penerapan pembelajaran menggunakan model pembelajaran berbasis masalah.

\section{DAFTAR RUJUKAN}

Benyamin Salu, Tadius. (2018). Pengaruh Metode Pembelajaran Jelajah Alam Sekitar (JAS) Terhadap Motivasi dan Hasil Belajar IPA Siswa Kelas VI SDN 1 Rantepao Kab. Toraja Utara. Jurnal Keguruan dan Ilmu Pendidikan, 7(3), 36-53.

Putu Budi susila, Dewa Kade Tastra, Ngurah Japa. (2014). Pengaruh Pembelajaran Berbasis Masalah Terhadap Kemampuan Berpikir Kritis Siswa Pada Mata Pelajaran Matematika Kelas IV Gugus III Kecamatan Busungbiu. Journal Mimbar PGSD Universitas Pendidikan Ganesha Jurusan PGSD, 2(1).

Damanhuri Daud, Mahmud Alpusari. (2011). Bahan Ajar Pendidikan Ipa Sekolah Dasar. Pekanbaru: Universitas Riau.

Ilham Handika, Muhammad Nur Wangid. (2013). Pengaruh Pembelajaran Berbasis Masalah terhadap Penguasaan Konsep dan Keterampilan Proses Sains Siswa Kelas V. Jurnal Prima Edukasia, I(1).

I Wayan Wijaya, I Wayan Lasmawan, I Wayan Suastra. (2015). Pengaruh Model Pembelajaran Berbasis Masalah Terhadap Hasil Belajar IPA ditinjau dari Minat Siswa terhadap Pelajaran IPA pada Siswa SD di Gugus IV Kecamatan Manggis. e- Journal Program Pascasarjana Universitas Pendidikan Ganesha, $5,1-8$.

Hendry Vebriana ,Yemima dan Ariyanti, Gregoria. (2015). Pengaruh Pembelajaran Berbasis Masalah $(\mathrm{Pbm})$ dengan Pendekatan Open-Ended Problem terhadap Kemampuan Berpikir Kritis Matematika Siswa SMP. Jurnal Educatio Vitae, 2(2).

Miftahul Huda. (2013). Model-Model Pengajaran dan Pengajaran. Malang: Pustaka Pelajar

Ratna Dewi, Musa Thahir. (2018). Prestasi Belajar Akuntansi Melalui Model Pembelajaran Problem Based Learning Pada Siswa Kelas XI MA Al Hidayah Muara Telang Kabupaten Banyuasin. Instructional Development Journal, 1(1), 1-8.

Nina Nurliani, Herman Subarjah, Atep Sujana. (2016). Pengaruh Model Pembelajaran Berbasis Masalah terhadap Hasil Belajar Peserta Didik Pada Materi Peristiwa Alam. Jurnal Pena Ilmiah, 1(1), 981-990.

Oemar Hamalik. (2013). Proses Belajar Mengajar. Jakarta: Bumi Aksara.

Suharsimi Arikunto, Suhardjono, dan Supardi. (2015). Penelitian Tindakan Kelas. Jakarta: Bina Aksara.

Trianto. (2013). Mendesain Model Pembelajaran Inovatif-Progresif. Jakarta: Kencana.

Wina Sanjaya. (2016). Strategi Pembelajaran Berorientasi Standar Proses Pendidikan. Jakarta: Kencana.

Zainal Aqib, dkk. (2014). Penelitian Tindakan Kelas. Bandung: Yrama Widya. 